жіровообрацение, функции эндокринной жкелезистой системы понижаются (особенно щитовидной железы), а вместе с тем ослабевают и процессы сгорания, регенерация ле и рост после голодания усиливаются. С терапевтическою целью, по $\mathrm{R}$ i c h t e r'y (Deut. m. W., 1928, o 26), это может быть использовано при ожирении, подагре и диабете, при гломерулонефрите и әклампсии, как равно в некоторых случаях a.лергических болезней, астмы, крапивниц, отека Q u in ck e и т. д.

\title{
ж) Хирургия.
}

23. Методы андстезии, применяемье а.иериканскими хирураии paзйрает Santon (Ann. of surg., v. 86, № 2, 1927) на основании огроса 640 операторов. Оказалось, что хлороформ всеми оставлен как при больших, так и при малых операция. $85 \%$ хирургов при лапаротомиях прибегают к применению эфира. IIри малых лапаротомиях многие пользуются и другими видами обезболивания$33^{\circ} / 0$ чието-местным обезболиванием, 42\% гнми видами наркоза и только $5 \%$-люмбальной анэстезией. $67 \%$ хирургов не применяют совсем люмбальной анәстезии, причем некоторые оставили ее после многочисленных испытаний (до 1056 сл.), убедившись, что она дает ряд осложнений, которых нельзя избежать. $90^{\circ} \%$ из всех хирургов, применяющих люмбальную анэ. стезию, пользуются ей только в известных случаях, в том числе $22 \%$ при гинекологических операщия. Довольно распространенным у американских хирургов является шрименение окиси азота и этилена в чистом виде или, еще чаще, в сочетании c эфирон.

A. T.

24. Поврелсдение глаз при эяирнол наркозе. У одного больного после операции, сделанной под әфирным наркозом, была обнаружена поверхностная язва роговицы, зажившая с образованием рубца. Чтобы выяснить, действительно ли в әтом случае причиной заболевания роговицы был попавший на нее эфир, J endralsky (Arch. f. Opht., Bd. 118) произвел на кроликах ряд опытов с орошением г.лаз әфиром. Оказалось, что результатом этого были покраснение и отек коньюнктивы и слущивание эпителия роговищы, каговые явления быстро проходили без следа. Отсюда автор думает, что повреждение роговиды в указанном случае зависе.ло не от әфира, а от гаких-либо механических причин.

$P$.

25. Бантериология и серотерапия острого аппендииита. W e in be rg, Prévot, D) avesne и Renard (Ann. de l'Inst. Past., 1928, № 10) на основании материала, обнимающего свыше 200 случаев острого аппендицита, среди ғоторых треть принадлежала $і$ гангренозной форме, нашли,-вопреки заявлению некоторых авторов,-что острый апшендицит без содержания микробов в отростке представляет исключительную редкость. Что касается встречающихся при этой болезни микробов, то лишь в редких случаях это-какой-либо один микроб, большей же частью болезнь вызывается несколькими формами микробов, обычно (в $2 / 3$ всех случаях) двумя или тремя. Среди этих микробов фигурируют все представители кишечной флоры, как аэробные,-особенно b. coli (в 87\%), энтерококк (в $30 \%$ и др.,-так и анаэробные-особенно b. perfringens (в $30 \%$ ), Gr a mнегативные палочки (в 39\%) и пр. При этом аэробы встречаютея как при гангренозном, так и при негангренозном аппендиците, анаэробы же-преимущество при гангренозной форме болезни. Мономикробный апнендицит всегда бывает обязан своим возникновением аэробам. Из гомбинаций микробов особенно часто встречается сочетание b. coli c b. perfringens. Как личный ошыт авторов, так и многочисленные наблюдения хирургов свидетельствуют о благотворном лечебном эффекте при аппендицие сывороток, именно, смеси моновалентных сывороток, направленных против тех микробов, которые особенно часто являются возбудителями болезни. Особенно хоропие результаты дает антигангренознал сыворотка с прибавлением serum anticoli. Сыворотка эта, в тяжелых случаях аппендицита, впрыскивается в количестве 60 - 80 куб. с., причем, если операция предшринимается немедленно, инъекция ее шроизводится в гонце оперативного вмепательства.

B. Сергеев.

26. Реиняузия изливиейся крови. Пзучение литературы по обратному переливанию излившейся в серозные полости крови и соб́ственные клинико-экспериментальные наблюдения позволили А. И. Ф и л а т о в у (Жћрн. совр. хир., 1928, вып. 3) сделать следующие общие заключения: 1) Вредные последствия при обратном переливании крови зависят от вливания гэмолизированной крови. При спонтанном дефибринировании грови в брюпной полости она не делается токсичной. Гәмолиз грови может быть обусловлен либо разрупением ее в поласти, чего в пер- 